
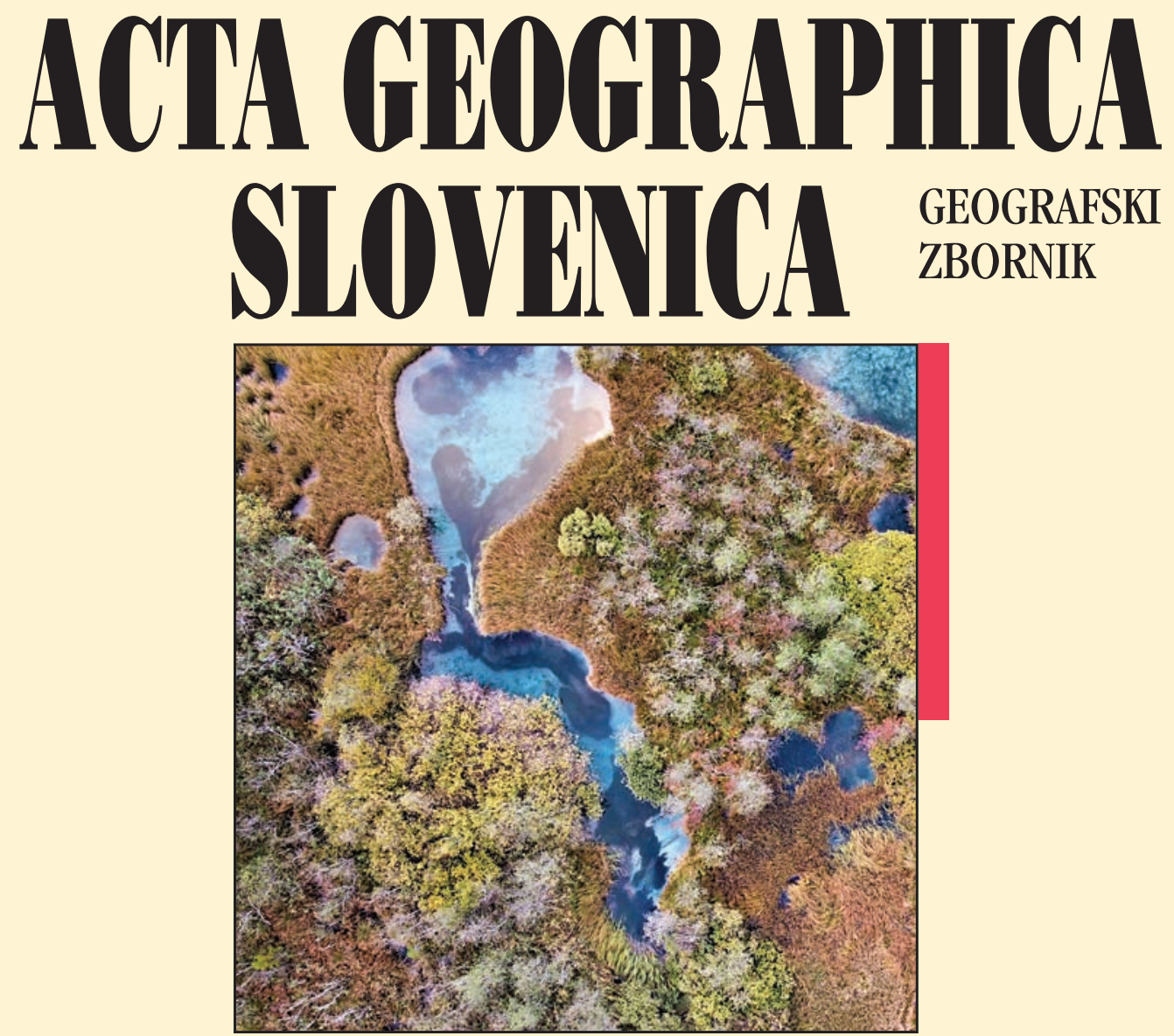

2021

61

2 


\section{ACTA GEOGRAPHICA SLOVENICA GEOGRAFSKI ZBORNIK 61-2 • 2021}

\section{Contents}

Đorđije VASILJEVIĆ, Milica BEGAN, Miroslav VUJIČIĆ, Thomas HOSE, Uglješa STANKOV

Does geosite interpretation lead to conservation? A case study of the Sićevo Gorge (Serbia)

Gabrijela POPOVIĆ, Dragiša STANUJKIĆ, Predrag MIMOVIĆ, Goran MILOVANOVIĆ, Darjan KARABAŠEVIĆ, Pavle BRZAKOVIĆ, Aleksandar BRZAKOVIĆ

An integrated SWOT - extended PIPRECIA model for identifying key determinants of tourism development: The case of Serbia

Robert KALBARCZYK, Eliza KALBARCZYK

Precipitation variability, trends and regions in Poland: Temporal and spatial distribution in the years 1951-2018

Ivana CRLJENKO, Matjaž GERŠIČ

A comparison of the beginnings of exonym standardization in Croatian and Slovenian

Tadej BREZINA, Jernej TIRAN, Matej OGRIN, Barbara LAA

COVID-19 impact on daily mobility in Slovenia

Maruša GOLUŽA, Maruška ŠUBIC-KOVAČ, Drago KOS, David BOLE

How the state legitimizes national development projects: The Third Development Axis case study, Slovenia

Tin LUKIĆ, Tanja MICIĆ PONJIGER, Biljana BASARIN, Dušan SAKULSKI, Milivoj GAVRILOV, Slobodan MARKOVIĆ, Matija ZORN, Blaž KOMAC, Miško MILANOVIĆ, Dragoslav PAVIĆ, Minučer MESAROŠ, Nemanja MARKOVIĆ, Uroš DURLEVIĆ, Cezar MORAR, Aleksandar PETROVIĆ Application of Angot precipitation index in the assessment of rainfall erosivity: Vojvodina Region case study (North Serbia)

Janij OBLAK, Mira KOBOLD, Mojca ŠRAJ

The influence of climate change on discharge fluctuations in Slovenian rivers

Vladimir STOJANOVIĆ, Dubravka MILIĆ, Sanja OBRADOVIĆ, Jovana VANOVAC, Dimitrije RADIŠIĆ

The role of ecotourism in community development: The case of the Zasavica Special Nature Reserve, Serbia

Marko V. MILOŠEVIĆ, Dragoljub ŠTRBAC, Jelena ĆALIĆ, Milan RADOVANOVIĆ Detection of earthflow dynamics using medium-resolution digital terrain models: Diachronic perspective of the Jovac earthflow, Southern Serbia

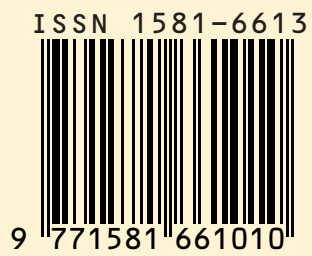




\section{DOES GEOSITE INTERPRETATION LEAD TO CONSERVATION? A CASE STUDY OF THE SIĆEVO GORGE (SERBIA)}

Đorđije Vasiljević, Milica Began, Miroslav Vujičić, Thomas Hose, Uglješa Stankov

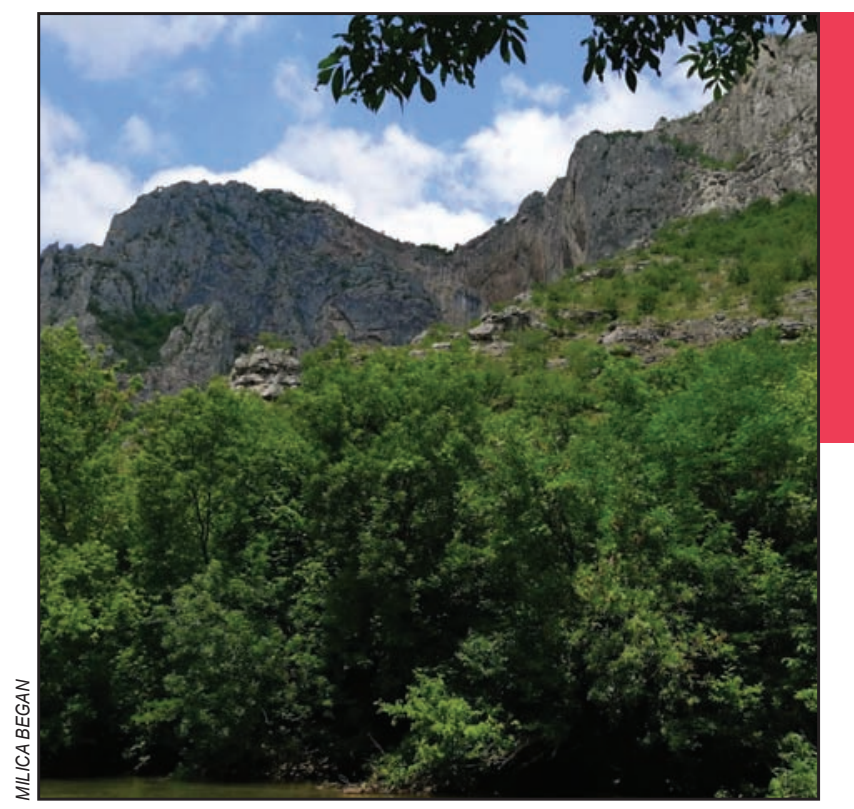

The landscape of the Sićevo Gorge. 
DOI: https://doi.org/10.3986/AGS.8753

UDC: 913:551.435.11:502.13(497.11)

COBISS: 1.01

Đorđije Vasiljević, ${ }^{1}$ Milica Began, ${ }^{1}$ Miroslav Vujičić, ${ }^{1}$ Thomas Hose, ${ }^{1,2}$ Uglješa Stankov ${ }^{1}$

\title{
Does geosite interpretation lead to conservation? A case study of the Sićevo Gorge (Serbia)
}

\begin{abstract}
People have appreciated the beauty of natural landscapes, the result of the interplay of different natural processes, for at least three hundred years in Europe. Many have been inspired by this beauty to promote such places for visits by others. Some have understood the importance of individual places visited within the local or regional environmental system. This has led to definitions and the establishment of protected areas with special visitor rules and regulations. This article presents a case study of Sićevo Gorge Nature Park in Serbia and an opportunity to transform it into a geoheritage site, underpinned by developing its interpretation based on the results of a study using the analytical-hierarchy process (AHP) method.
\end{abstract}

KEYWORDS: geoheritage, interpretation, gorges, Sićevo, Serbia

\section{Ali interpretacija območij geološke dediščine zagotavlja njihovo ohranjanje? Primer soteske Sićevo v Srbiji}

POVZETEK: V Evropi ljudje že več kot 300 let občudujejo lepoto naravnih pokrajin, ki je rezultat medsebojnega učinkovanja različnih naravnih procesov. Mnoge je ta lepota spodbudila k temu, da so take kraje promovirali kot prostore, vredne obiska, nekateri pa so razumeli tudi pomen posameznih krajev, ki so jih obiskali, v lokalnem ali regionalnem okolju. Na tej podlagi so bila opredeljena in ustanovljena zavarovana območja s posebnimi pravili in predpisi za obiskovalce. V članku je obravnavan primer naravnega parka soteske Sićevo v Srbiji in možnost njegove preobrazbe v območje geološke dediščine na podlagi oblikovanja njegove interpretacije v skladu z izsledki raziskave, v kateri je bila uporabljena metoda analitičnega hierarhičnega procesa (AHP).

KLJUČNE BESEDE: geološka dediščina, interpretacija, soteske, Sićevo, Srbija

This article was submitted for publication on July $2^{\text {nd }}, 2020$.

Uredništvo je prejelo prispevek 2. julija 2020.

\footnotetext{
${ }^{1}$ University of Novi Sad, Faculty of Sciences, Department of Geography, Tourism, and Hotel Management, Novi Sad, Serbia dj.vasiljevic@dgt.uns.ac.rs (https://orcid.org/0000-0002-1225-4409), voyageouse@gmail.com (https://orcid.org/0000-0003-2629-2040), miroslav.vujicic@dgt.uns.ac.rs (https://orcid.org/ 0000-0003-0003-7869), t.hose123@btinternet.com (https://orcid.org/0000-0001-5699-7389), ugljesa.stankov@dgt.uns.ac.rs (https://orcid.org/0000-0002-7731-592X)

${ }^{2}$ University of Bristol, School of Earth Sciences, Bristol, United Kingdom t.hose123@btinternet.com (https://orcid.org/0000-0001-5699-7389)
} 


\section{Introduction}

Geoconservation, as a fairly recently recognized discipline (Larwood 2016) within the Earth sciences, provides information useful for solving environmental problems of social relevance, such as inappropriate land-use planning and geo-exploitation (Hose 2011), which might endanger the physical integrity of geoheritage (Henriques et al. 2011). In addition, it designs suitable and specialized services necessary and appropriate for their mitigation. Geoconservation is an important discipline in conserving abiotic nature and, thanks to its various methods, it can be used as an educational tool. It also can be designed to simultaneously preserve nature, educate, and create profit. It thus defines a body of knowledge crucially important to the creation of products (interpretative geotrails, geo-reserves, and geoparks) that, in addition to guaranteeing the protection of abiotic nature, are capable of promoting economic and social development at every scale from local to global - that is, geotourism (Hose 1997; 2011) - extending to current interpretations of sustainable development. Activities undertaken in, and travelers' journeys into, wild and natural landscapes that would now be subsumed within geotourism can be recognized in Europe (Hose 2016), including Serbia (Vasiljević, Marković and Vujičić 2016), since at least the late seventeenth century.

This study presents research on three stakeholder groups (visitors, guides, and experts) that use various interpretation tools for different purposes during their visits to the case study area, the Sićevo Gorge in eastern Serbia. The aim is to discover how various users of natural areas perceive interpretation, and which of its instruments and tools they find most relevant. Such information is useful for managing protected areas and for nature-based tourism (such as geotourism and ecotourism) in creating enjoyable experiences for visitors and satisfying them while ensuring sustainability (in terms of nature conservation).

\section{Geoheritage interpretation in brief}

The use of suitable presentation techniques can make complex and difficult geological and geomorphological phenomena, as elements of geoheritage, both interesting and easier for the public to understand. Generally, there are two reasons why geoheritage needs to be presented. First, it is important in underpinning well-known landscapes and geodiversity. Despite this, geoheritage is farthest from the public in terms of knowledge, interests, and general presentation in comparison to other more easily identifiable aspects of natural heritage, especially biodiversity. However, similar to biodiversity, geoheritage is vulnerable to both human activities and various natural processes that might damage it (Komac, Zorn and Erhartič 2011). The damage is long-term and difficult, often impossible, to remediate. Therefore, only those people and local communities that are aware of their geoheritage, and can both identify with and relate to it, can contribute to its conservation and sustainable development. Geoheritage presentation has a clear role in establishing real links between biodiversity and geodiversity, and the equal need to preserve them.

Second, geoheritage presentation supports the opportunity that geodiversity offers for tourism development at the local and national levels. The sound explanation and presentation of geological and geomorphological phenomena will enhance the visitor experience and help boost geotourism potentials (Štrba, Baláž and Lukáč 2016). The interpretation of geoheritage is considered the art of explaining the meaning and significance of geosites to visitors (Xu et al. 2015). The modern idea of interpretation was born in the United States, where Tilden (1977) suggested that producing pamphlets could help tourists understand unfamiliar aspects of nature, including a geological phenomenon in Yellowstone National Park that was misunderstood by them. After the idea's success, guided tours by park rangers and concessioners were offered, and the first nature interpretation program by the United States National Parks Service (Nunes 1991; Began et al. 2016) was created. According to the World Tourism Organization (WTO) and United Nations Environment Programme (UNEP), education and interpretation are key elements of visitor provision used by administrators to better manage and provide for tourists (Making ... 2005) and meet their needs.

Environmental interpretation (Pierssene 1999) is part of environmental education (Ballantyne 1998), being the term used to describe communication activities undertaken to better understand the natural environment in protected areas, nature parks, national parks, natural history museums, and other venues (Vasconcelos 2003). Its provision aims to preserve and conserve natural resources and seeks to increase visitor satisfaction, serving as a management tool. Ham (1992) argues that it is a form of communication, a language that translates technical science, environmental science, and related matters into 
readily understandable terms and ideas for people without scientific training or inclination. It aims to sensitize visitors to see, explore, observe, analyze, understand, and engender feelings for natural heritage, including geological heritage, that they visit. To reveal the deeper meaning of a historical reality or a landscape, it is essential to carry out research and follow its results. Thus, Werner (1996) explains that visitors should be offered interpretations of heritage, not inventions or distortions. Murta and Albano (2005) suggest that to interpret heritage is to present places and cultures to visitors and to enrich their experience. Environmental interpretation is "a technique flexible and malleable to different situations « (César et al. 2007). Thus, it can and should be performed to the advantage of the geology and geomorphology of an area with significant geoheritage. Generally, such interpretation is particularly necessary for the purposes of geotourism (Hose et al. 2011; Vasiljević et al. 2011), ecotourism (Mastrini et al. 2018), and sustainable tourism (Moreira 2012; Began et al. 2016).

\section{Study area}

The Sićevo Gorge (Sićevačka klisura) lies along the Nišava River (Figure 1). It connects the Bela Palanka Basin (Belopalančka kotlina) to the east with the lower Nišava Valley (Ponišavlje) to the west. The lithological basis of the Sićevo Gorge is Paleozoic, Mesozoic, and Tertiary-Neogene sandstones and limestones (Figure 2). Quaternary rock, primarily alluvial deposits, and scree frequently obscure them as well as creating their own landforms. Locally known as the »Serbian Cappadocia (National Geographic Srbija, 2016) it is an oasis of rare plants and animals, the setting of various geosites, and an important cultural, historical, and religious location. A Roman military road, the Via Militaris (Figure 3b), was constructed here in the first century $\mathrm{AD}$ and was used later during Ottoman rule, from the fourteenth to the early twentieth centuries, in the Balkans. Hence, many different civilizations have traveled through this gorge, underpinning its historical and cultural significance.

Kostić (1954) distinguishes three morphological units (Figure 2) in the gorge. The easternmost part, about $7 \mathrm{~km}$ long, is called the Gradište Canyon (Gradiški kanjon, locally known as Gradištanski kanjon) after the nearby village of Gradište, although this part of the gorge also carries a number of other names: Upper Gorge (Gornja klisura), Big Sićevo Gorge (Velika sićevačka klisura), Ostrovica Gorge (Ostrovička klisura), Crnče-Gradište Canyon (Crnačko-gradištanska klisura), and Ostrovica-Gradište Canyon (Ostrovičko-gradištanska klisura). The second unit is the Ostrovica extension and the third is the Prosek Gorge (Prosečka klisura).

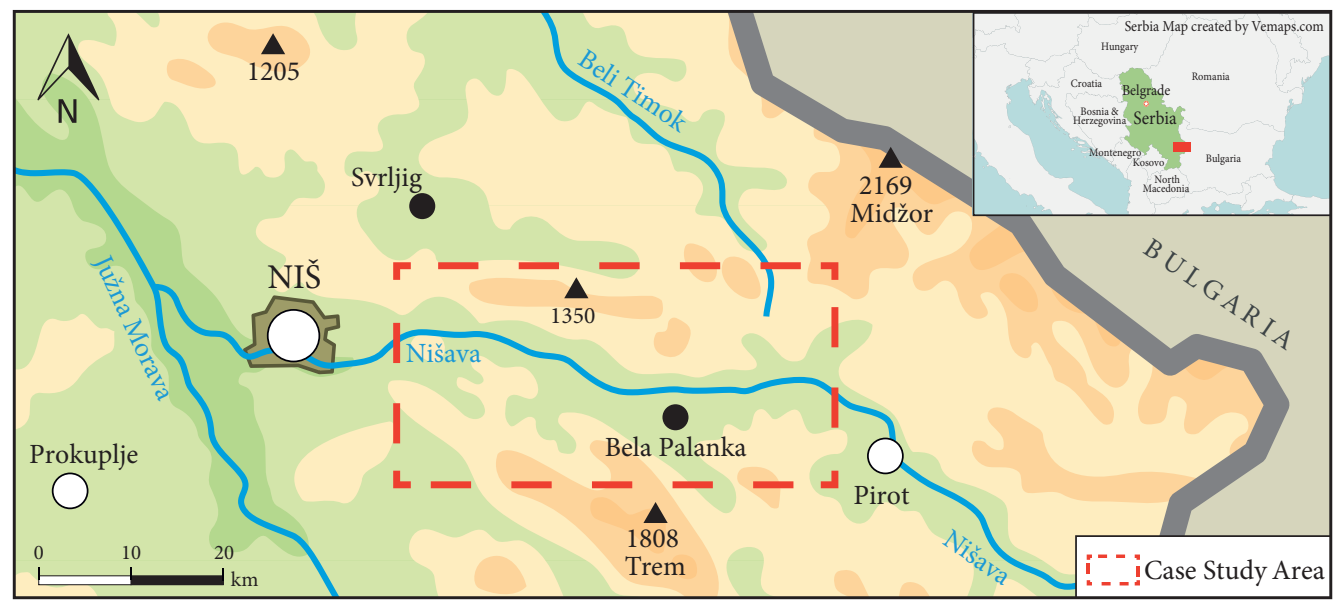

Figure 1: Geographical position of the Sićevo Gorge. 
Acta geographica Slovenica, 61-2, 2021

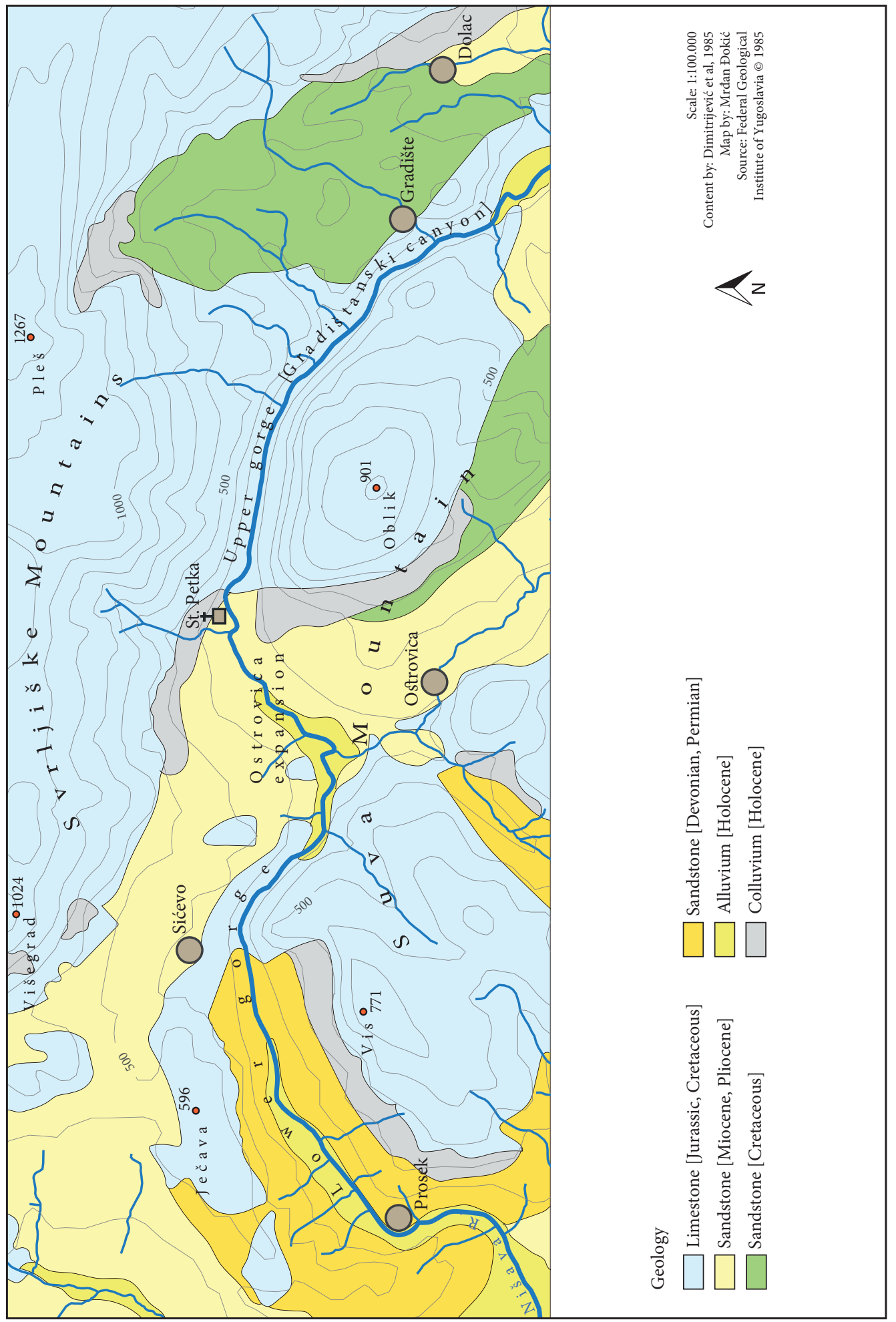


Mitić (2006) divided the Sićevo Gorge into two parts: the upper part (the canyon) and the lower part (the gorge). Ćirić (2006) distinguished four parts: the Svrljig Mountains (Svrljiške planine), part of the Ploče Plateau (visoravan Ploče) and the Kunovica area (with Mount Oblik and Mount Kusača), the Ostrovica Basin (Ostrovička kotlina), and the Sićevo Gorge. In the Sićevo Gorge, the same author distinguished three parts: the Gradište Canyon, the passage through the Ostrovica Basin, and again the Sićevo Gorge in the narrow sense (Began et al. 2016). The same author continues description of the study area: »The canyon part of the Sićevo Gorge, Gradište Canyon, cuts between Mount Oblik (901 m) to the north and the Svrljig Mountains (Mount Golubnjak, 1,179 m; Mount Pleš, 1,267 m; and Mount Tupanar, 1,106 m) to the south. The canyon consists of steep and vertical, often terraced rocky cliffs. The width of the canyon at the bottom is mainly reduced to the bed of the Nišava River. The height of the rocky canyon walls reaches about $400 \mathrm{~m}$ on the north side of Mount Oblik, whereas the average direct canyon depth to the valley is about $250 \mathrm{~m}$. The south side of the canyon extends continuously, with the exception of the valley of Babica Creek, where the Nišava River flows into the gorge. The north side is cut by the valleys of several small intermittent tributaries of the Nišava River, as well as steep longitudinal profiles and hanging valleys (Began 2019, 92).

Downstream from the Gradište Canyon, approximately between the St. Petka Monastery (Figure 3d) and the mouth of Ostrovica Creek (Ostrovički potok), the Nišava River flows through a basin extension, with a wide bottom and slightly sloping sides, about $2 \mathrm{~km}$ long. This extension is tectonically predisposed and built in the domain of the small Neogene Ostrovica Basin and St. Petka Basin, and then transformed by fluvial and denudation processes. The belt of lower terrain runs deep toward the southeastern countryside around the gorge along the valley of Ostrovica Creek, all the way to the village of Ravni Do (Mitić 2006).
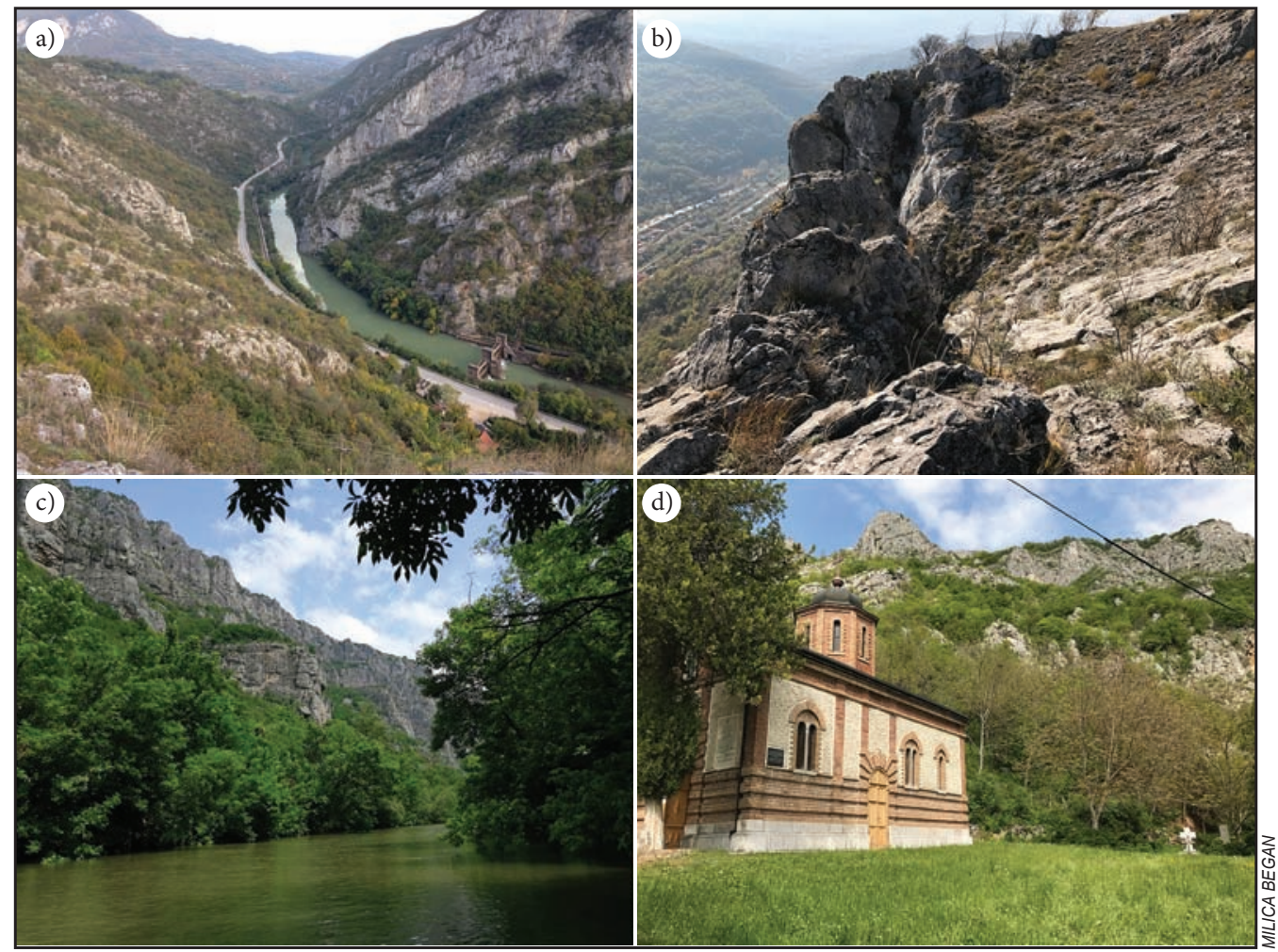

Figure 3: Scenery and landmarks of the Sićevo Gorge. (a) The edge of the village of Sićevo; (b) The exit of the gorge toward Niš (part of the Via Militaris is best preserved here, but barely visible); (c) The slopes of the gorge seen from the river; (d) The St. Petka Monastery in the village of Ostrovica. 
The part of the valley downstream from the St. Petka Basin is called the Prosek Gorge (Prosečka klisura). It is about $8 \mathrm{~km}$ long and is morphologically very diverse. The first, most upstream part of it, $1.5 \mathrm{~km}$ in length, is in the southeastern part of the gorge, next to vertical rocky cliffs over $200 \mathrm{~m}$ high and steep, occasionally vertical sections about $150 \mathrm{~m}$ high on the north (Brljavski kamen 'Dirty Cliff'). At the end of this narrowed sector of the valley, approximately at the line of the village of Sićevo, the Nišava River completely cuts through the complex limestone rocks and begins to cut into the substrate of Devonian and Permian sandstones, conglomerates, siltstone, and clays. Due to the lesser resistance of these rocks to erosional processes, the bottom parts of the valley lost their typical gorge features; that is, the valley sides are less steep and the valley floor widens. In the limestone rocks that build the upper, higher sections of the valley, the sides form rock sections, both on Mount Ječava to the north and Mount Kusača to the south. However, those sections away from the river, with the particularly impressive limestone excavations of Mount Kusača, are lined up in an arched, amphitheatrical series.

At the base of these sections there is a belt of steeply sloping screes, and below them slightly gentler sloping terrain constructed of Paleozoic rocks. Downstream from the line on which the limestones of both Mount Kusača and Mount Ječava end to the west, along the line from Red Hill (Crveno brdo) to the village of Prosek, in the double bend of the Nišava River, the valley is built of Permian red sandstones and, due to the steeper slopes and slightly narrower bottom, the river cut meanders (Krumin 2006; Mitić 2006; Began 2019).

Above the gorge, the limestone plateaus are pockmarked with dolines (Krumin 2006). The Sićevo Gorge is rich in underground karst features, mainly caves without speleothems. Most of the caves are preserved in their natural condition and are hydrographically dry. The rapid cutting of the Nišava River into the Sićevo Gorge and the onset of deep karstification did not allow more constant underground flows a given level and thus the development of larger cave channels. The most common Serbian term for these small caves is dupke (Jovanović 1891). Big Balanica Cave (Velika Balanica, $20 \mathrm{~m}$ long) and Little Balanica Cave (Mala Balanica, $12 \mathrm{~m}$ long) are the best known and most explored in the Sićevo Gorge, located near the village of Sićevo. The entrances to both caves are at an elevation of $332 \mathrm{~m}$ and they are only $7 \mathrm{~m}$ apart. Pleistocene deposits, mammalian fossils, and Paleolithic worked flint remains have been found in both caves. The remains date to the Middle Pleistocene: nine teeth and seven bones from hands and feet, as well as a human jaw, which has been described as a remnant of archaic Homo sapiens (Roksandić et al. 2011; Cvetković and Dimitrijević 2014); cave bear remains were also found here (Began 2019). In the gorge area there are a large number of springs with karst water or through which free water discharges in Neogene sediments and Paleozoic rock (Kostić and Martinović 1967).

\section{Methods}

In order to achieve the study's goals, the authors employed the analytical-hierarchy process (AHP), a systematic approach developed by Saaty (1980) and used in multi-criteria decision-making. The AHP presents a multi-criteria decision-making methodology that is noteworthy for its acceptance of the subjective nature of the information used in many decision-making contexts (Hsu, Tsai and Wu 2009). Through its operations, the subjectivities and biases given in individual responses can be factored into the model, allowing for the gradual refinement of decision-making criteria, which means that it is particularly relevant in the context of tourism development and planning, in which, for example, decisions about resource allocation and promotion can be contestable and problematic.

With complex decisions, due to different criteria and alternatives, the decision-making process becomes complex, comprising mutually connected and dependent factors, further influencing the final decision (Jandrić and Srđević 2000). The AHP provides solutions to complex problems and employs hierarchical structures through developing priorities for different alternatives determined by the decision-makers (Brushan and Rai 2004). Its final output is an evaluation model for decision-making, dependent upon weighted criteria. It integrates different measures into a single overall score for ranking decision alternatives (Hsu, Tsai and $\mathrm{Wu}$ 2009). It is used to simplify multiple criterion problems by deconstructing them into a multilevel hierarchical structure (Harker and Vargas 1987) because it gradually compares alternatives and measures their impact on the final decision-making goal; this helps decision-makers in their choices between competing alternatives (Saaty 1980). 
Given a pairwise comparison, the AHP analysis involves three tasks: 1) developing a comparison matrix at each level of the hierarchy starting from the second level and working down, 2) computing the relative weights for each element of the hierarchy, and 3) estimating the consistency ratio (CR) to check the consistency of the judgment (Božić et al. 2018; Vujičić et al. 2020). If the consistency ratio (CR) is less than 0.10 , the result is sufficiently accurate and there is no need for adjustments in comparison or for repeating the calculation. If the ratio of consistency is greater than 0.10 , the results should be reanalyzed to determine the reasons for inconsistencies and to remove them by partial repetition of the pairwise comparison. When repetition of the procedure in several steps does not lead to reduction of the consistency to the tolerable limit of 0.10 , all the results should be discarded and the entire procedure should be repeated from the beginning (Jandrić and Srđević 2000). In order to evaluate the criteria weight for attitudes toward interpretation means among respondents that have visited, researched, or worked at the Sićevo Gorge, the authors first developed a hierarchically structured model (Figure 4) based on certain indicators, adapted from Vujičić et al. $(2011 ; 2018)$ and Petrović et al. (2013). They then applied the AHP model, a method with increasing application in tourism research literature (Scholl et al. 2005).

\subsection{Study sample}

The sampling strategy for the AHP method can be based on a suitably chosen purposeful sample that is appropriate for generating qualitative data, useful for research focusing on a specific issue for which a large sample is not necessary, especially in tightly bounded case studies (Lam and Zhao 1998; Cheng, Li and Ho 2002). Purposeful sampling (Coyne 1997) was deemed appropriate for this research because of the limited need for generalization from the case study (Creswell 2007). Cheng and $\mathrm{Li}$ (2002) argue that the AHP method is in fact made impractical in research with a large sample size because »cold-called " non-expert respondents may have a great tendency to provide arbitrary answers, resulting in a very high degree of inconsistency, which invalidates the approach (Wong and Li 2008). The data were collected within a case study, in which questionnaires were distributed by the researchers into a purposefully selected sample population. These were subdivided into three groups: 1) ten guides (tour guides experienced in nature-based tourism); 2) ten experts (tourism experts, geosite experts, geoheritage experts, hikers, and geographers); and 3) ten individuals (respondents that had visited the Sićevo Gorge). Thus, the final sample consisted of thirty respondents of various ages, nationalities, and sexes.

\subsection{Questionnaire design and research phases}

Research design and implementation have been particularly well and concisely covered by the Tourism and Recreation Research Unit (1983) in the United Kingdom; it covers many of the research terms employed

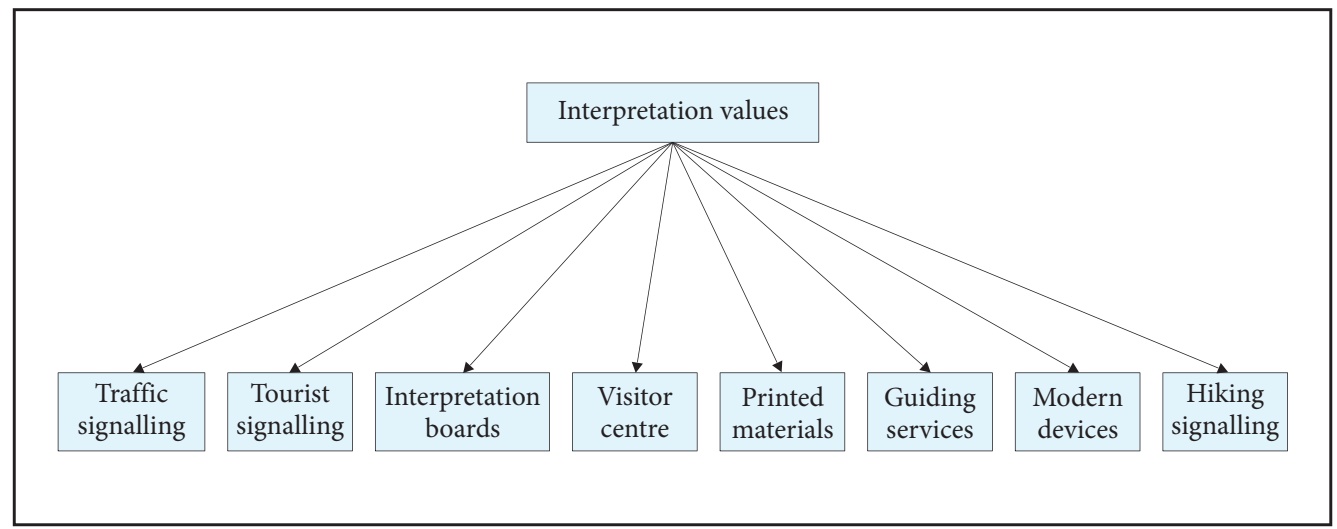

Figure 4: Scheme of various interpretation and signaling tools presented to respondents. 
herein. The first phase of the research included a review of relevant previous literature (Vujičić et al. 2011, 2018; Petrović 2013; Višnić, Spasojević and Vujičić 2016) and the selection of all the factors defining interpretation tools, thus helping define the final model based on the modified indicators created by Vujičić et al. (2011). The authors selected eight indicators (Figure 4) to be measured by the AHP model. The indicators are formed according to the most relevant factors included in the decision-making process. After the selection of the factors and the design of the questionnaires, the second phase of the research was initiated; this included the interviewed respondents, as well as the entry of the collected data into the statistical computer program Expert Choice 2000 - AHP Software for Decision Making and Risk Assessment (expertchoice.com). Finally, the consistency of the overall research was determined, as well as the final ranking of the factors, by calculating the weight coefficients.

\subsection{Procedure}

The research for this case study was conducted in 2018, from March through to June. The respondents participated in the research on a volunteer basis. All of them were thoroughly informed about the purpose of the research, as well as the researchers' identities. They were advised that their contributions would be recorded anonymously and that the data would be used strictly and solely for the purposes of the research. A structured interview, based on a preprinted questionnaire, was employed in which the interviewer asked set questions, filling in the answers on the questionnaire. In this way, any possible misunderstandings of the carefully derived questions were eliminated.

Respondents were asked to express their attitudes toward interpretation tools when visiting geosites, measuring their importance factor by using Saaty's (1980) scale (Table 1). The authors gave brief standardized explanations of each criterion (or factor) before and during the structured interview. The respondents were required to assign a corresponding numerical value (Saaty's scale) to different factors based on the relative importance they considered the factor had for them.

\section{Table 1: Saaty's scale for pairwise comparisons in AHP. An intermediate numerical value of 2, 4, 6, 8 and 1/2,1/4, 1/6, 1/8 can be used as well} (Saaty 1980).

\begin{tabular}{lc}
\hline Judgment term (elements A and B) & Numerical term \\
\hline Absolute preference (A over B) & 9 \\
Very strong preference (A over B) & 7 \\
Strong preference (A over B) & 5 \\
Weak preference (A over B) & 3 \\
Indifference of A and B & 1 \\
Weak preference (A over B) & $1 / 3$ \\
Strong preference (A over B) & $1 / 5$ \\
Very strong preference (A over B) & $1 / 7$ \\
Absolute preference (A over B) & $1 / 9$ \\
\hline
\end{tabular}

In post-research group decision-making, an aggregation of each respondent's resulting priorities was computed using the geometric mean, which is more consistent with the meaning of priorities in AHP (Božić et al. 2017; Vujičić et al. 2018).

\section{Results}

The synergy of all responses (Figure 5) from the respondents shows that the most important factor for measuring interpretation tools is guiding services $(0.161)$, followed by tourist signalization $(0.144)$ and interpretative boards (0.138), whereas the least important factors are printed materials (0.102) and mountain signalization (0.106). The consistency ratio (CR) is 0.03 , which indicates that the study is reliable and accurate, and therefore there is no need for adjustments in the comparison of criteria. 
Figure 5 shows the significance of guiding services, which the respondents marked as far more important than all the other interpretation indicators. Guiding services can improve and bring interpretation to a completely new level. Irrespective of the available technology that can be employed, a competent guide will always be one of the best interpretation tools. Before taking any action for creating high-value interpretation in the Sićevo Gorge, it is necessary to offer appropriate geointerpretation training. There are a suitable number of tour guides in the city of Niš, but most of them do not have experience in geo-interpretation. There are also mountain guides, who lack experience in working with tourist groups. By setting up proper geo-interpretation training for both parties, it is possible to create high-quality geo-interpretation services.

Table 2 shows the weight of the preferences for interpretation tools among three different groups. Visitors rated guiding services $(0.200)$ the most important interpretation tool, followed by tourist signaling $(0.163)$ and interpretation boards (0.126), whereas the least important were modern devices (0.084) and hiking signaling (0.088).

Experts gave preference to and rated interpretation boards $(0.165)$ as the most important factor, followed by modern devices $(0.147)$ and hiking signaling $(0.141)$, whereas the least important are printed materials (0.097) and guiding services (0.100). The guides gave the highest score to guiding services $(0.231)$,

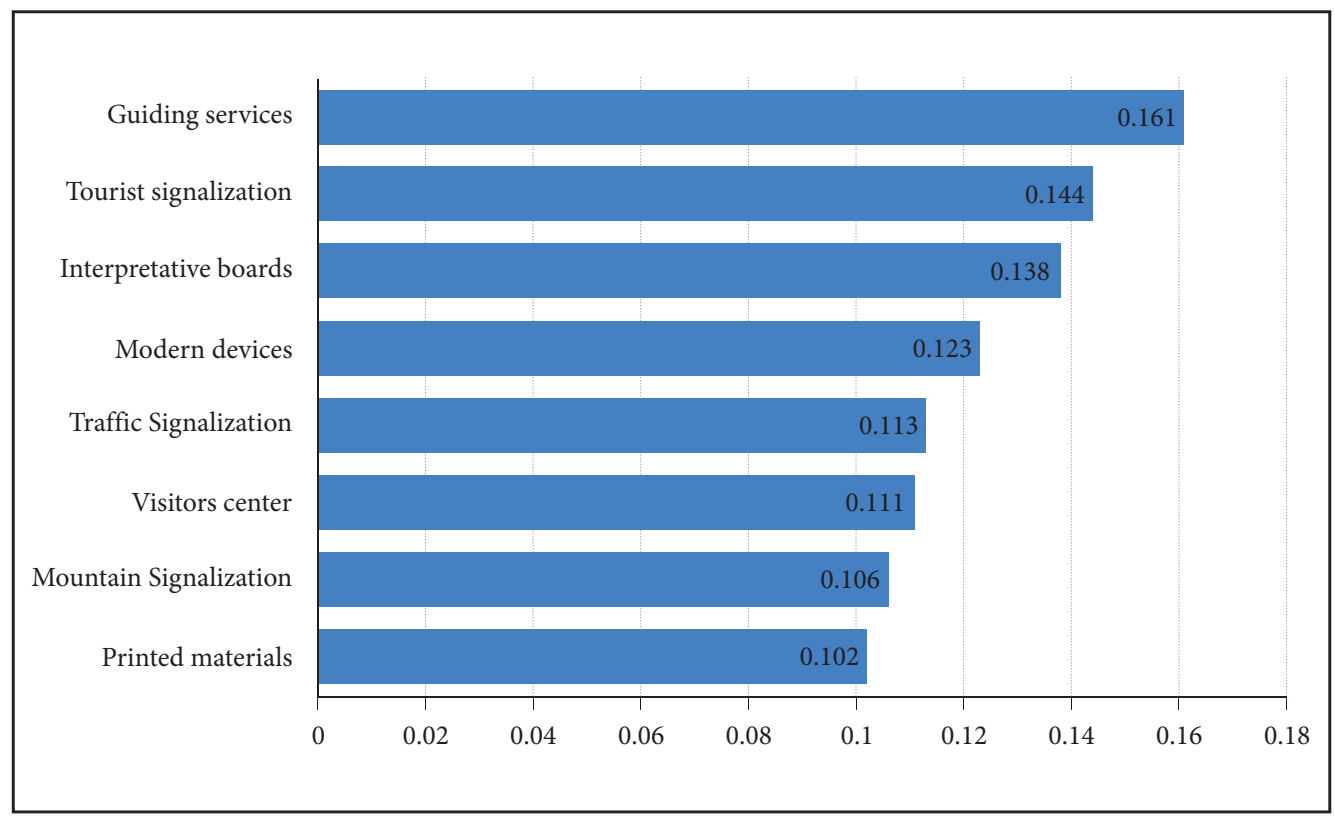

Figure 5: Synergy of all responses.

Table 2: Weight of preferences for interpretation tools among three different groups.

\begin{tabular}{lll}
\hline Visitors & Experts & Guides \\
\hline Guiding services (0.200) & Interpretation boards (0.165) & Guiding services $(0.231)$ \\
Tourist signaling (0.163) & Modern devices $(0.147)$ & Modern devices $(0.144)$ \\
Interpretation boards (0.126) & Hiking signaling $(0.141)$ & Tourist signaling $(0.129)$ \\
Printed materials $(0.117)$ & Tourist signaling $(0.132)$ & Interpretation boards $(0.108)$ \\
Visitor center $(0.113)$ & Traffic signaling $(0.115)$ & Visitor center $(0.108)$ \\
Traffic signaling $(0.110)$ & Visitor center $(0.102)$ & Traffic signaling $(0.105)$ \\
Hiking signaling $(0.088)$ & Guiding services $(0.100)$ & Printed materials $(0.088)$ \\
Modern devices $(0.084)$ & Printed materials $(0.097)$ & Hiking signaling $(0.086)$ \\
\hline
\end{tabular}


followed by modern devices (0.144) and tourist signaling (0.129), whereas the least important are hiking signaling (0.086) and printed materials (0.088). The consistency ratio (CR) for the visitors is 0.02 , for the experts it is 0.03 , and for the guides it is 0.04 , which means that this sample, as well as the result, is sufficiently reliable and accurate, and therefore there is no need for additional adjustments.

\section{Concluding remarks: management implications}

The interpretation of geoheritage and the dissemination of knowledge about the Earth is accomplished by various means and techniques, both in situ and ex situ and with or without the personal interaction of an interpreter (Hose 1995; 2000). The results of various indicators posed as questions to the respondents are presented in Tables 1 and 2. After considering the results, the authors propose various actions in order to improve geoheritage interpretation at the case study location.

The tourism-related respondents (visitors and guides) in general gave preference to guiding services and tourist signaling as important factors. This indicates that they consider these tools important elements of geoheritage protection and interpretation in the Sićevo Gorge. Highly trained and well-educated guides can both teach and develop visitors' positive feelings about the Sićevo Gorge, as well as showing them its best aspects. They can present visitors with geoheritage features and their values in the best way possible because they are in direct contact with the visitors. Because there are currently no specialized tour guides for the Sićevo Gorge, it is necessary to offer appropriate training for such guides and, following the example of best guiding practice in other geosites in Europe, teach them the skills of high-quality geoheritage guiding. The aforementioned Little and Big Balanica Caves are important and attractive archaeological sites, unique in Serbia. They should be evaluated, protected, and opened up to carefully managed visitors. The Balanica Caves' prehistoric finds have already attracted much attention; a properly developed interpretation scheme can both better present this site to current visitors and bring it to the attention of a wider audience.

What might also be useful in justifying interpretation as a tool for geoconservation is the high values assigned to signaling (in general) and interpretation boards by all three groups of respondents. Mountain signalization (even though this is basic signalization for any outdoor space) is least important for the respondents; the reason for this might be that most of the visitors that responded do not understand the meaning of this signalization. Tourist signalization and interpretative boards - which make the area more attractive when features that visitors see are explained - are the most important indicators for the respondents. The importance of interpretative boards must be emphasized, and significant attention should be paid to this means of interpretation. The organization and design of interpretation boards needs to be appropriate and follow one idea and storyline. Interpretation boards, or even QR codes that link to online resources as a more cost-effective solution, need to be installed at every attractive spot; however, overt visual intrusion should be avoided so that there are not so many boards that they become visually dominant in the natural landscape. They should interpret geological and geomorphological features in such a way as to provide visitors with interesting information that will engage them in further and future exploration. The information provided on the panels should contain facts of interest to various types of visitors, facts they did not already know, and facts specific to the area. The main idea should be a desire for visitors to leave the place satisfied, energized, more informed, and better aware of the significance of the place they have just visited. Special attention must be paid to this analogue interpretation means. Even though other better-developed and better-organized natural sites rely on modern digital devices (Stankov et al. 2019) more than on interpretation panels, the respondents' opinions show the importance of the interpretation panels, and this finding cannot be ignored.

Before explaining any kind of natural heritage to potential visitors, it is fundamentally necessary to waymark all the paths in the Sićevo Gorge and ensure that appropriate and adequate safety measures are in place. The Sićevo Gorge has always been a favorite place for many professional and amateur nature lovers, and so its paths are currently clearly marked with hiking signalization. All the signalization is clear and visible because it is remarked every spring and autumn. It should be noted that the hikers' signalization is for their specific purposes; this means that all potential visitors must know how to read and understand its specialized markings. However, it is possible to rely on this signalization to create paths for different types of visitors. Paths can be divided into sections, from easiest to hardest. The Kjugekull geosite (in Skåne county, Sweden) has established and marked paths throughout the entire geosite (e.g., yellow for easy, green 
Đorđije Vasiljević, Milica Began, Miroslav Vujičić, Thomas Hose, Uglješa Stankov, Does geosite interpretation lead to ...

for medium, and red for difficult). In this way, it is easy for visitors to follow the path most suited for them. At the start of every path, there is an information board with a map of the path, and information about its length and the approximate time needed to complete it. This idea can easily be implemented in the Sićevo Gorge because its terrain allows it to be marked and divided into easy, medium, and hard sections. This type of signage can also be attractive to visitors. The paths should include the most interesting features of the gorge along with interpretation panels that explain the most important and interesting facts about the features. The Sićevo Gorge is rich in cultural and historical heritage, biodiversity, geodiversity, and folk stories; including these within the overall interpretation will make it even more attractive and accessible to a wide range of visitors of different ages and interests.

Because the Sićevo Gorge was part of a historical Roman military road, the Via Militaris (Figure 3b), as well as part of the old Stambol road constructed during the Ottoman era, today it is possible to hike the paths that were parts of these roads, where visitors can feel a sense of history. This road also has attractive viewpoints and places of historical events that can be highlighted by attractive interpretation panels, maps, and photographs.

While creating and way-marking the walking and hiking paths, one must bear in mind health and safety precautions and do whatever is necessary to ensure that visitors will not experience any unwanted or serious events. Putting fences in dangerous places, constructing outdoor steps so that visitors can more easily tackle some of the hard inclines, and avoiding the most dangerous areas or constructing bridges over some of these can help visitors reach some of the parts that are attractive, but currently difficult and potentially dangerous. However, a balance needs to be struck between achieving greater and safer access for visitors other than hikers and avoiding damage to fragile habitats and detracting from the area's natural beauty with excessive artificial construction and signage; that is, sustainable ecotourism.

The results of this study should be taken into consideration when creating plans for protecting the Sićevo Gorge. It has already been protected as a nature park, but it needs to be further protected, especially for its geoheritage interest, by creating and implementing a detailed geoconservation plan. At the time of writing this article, only a few months after traffic was removed from the gorge to a new highway, the gorge is already fuller than in the past, with nature lovers using this new situation to better enjoy this incredible place. It is important to act quickly and implement all the geoconservation means, especially interpretation, in all future plans to protect this geological and geomorphological phenomenon for the benefit of future generations.

All three groups of respondents, with some essentially minor differences, gave preference to similar interpretation tools to raise awareness about these somewhat remote and rather fragile but attractive natural assets. In general, the case study results strongly indicate that interpretation tools can greatly assist in the conservation of geoheritage sites - that is, geoconservation. This is very much in keeping with the truism expressed some twenty years ago by the Greek geoconservationist Irini Theodossiou-Drandaki (2000) that there is »no conservation without education. « Although she touched upon environmental interpretation, she particularly focused on formal education and significantly noted that »listing a site will not guarantee its conservation and protection. This can only be accomplished by touching everybody's awareness and especially that of young people, who, learning of their home's geological heritage, will appreciate its value and will consequently protect it. « Environmental interpretation, as advocated by Tilden (1977) with its emphasis on not just providing educational information but on building empathy by revealing meanings and relationships through illustrative media such as outdoor panels - appears to have been validated by the respondents' preferences in this case study.

ACKNOWLEDGMENT: This work was supported by the Ministry of Education, Science, and Technological Development, Republic of Serbia (grant 176020).

\section{References}

Ballantyne, R. 1998: Interpreting 'visions': addressing environmental education goals through interpretation. Contemporary Issues in Heritage and Environmental Interpretation: Problems and Prospects. Norwich.

Began, M. 2019: Problemi konzervacije i mogućnosti interpretacije geodiverziteta kanjona i klisura jugoistočne Srbije. Ph.D. thesis. University of Novi Sad. Novi Sad. 
Began, M., Višnić, T., Djokić, M., Vasiljević, Dj. A. 2016: Interpretation possibilities of geoheritage in Southeastern Serbia - gorge and canyon study. Geoheritage 9. DOI: https://doi.org/10.1007/s12371-016-0197-9

Božić, S., Kennell, J., Vujičić, M. D., Jovanović, T. 2017: Urban tourist motivations: why visit Ljubljana? International Journal of Tourism Cities 4-3. DOI: https://doi.org/10.1108/IJTC-03-2017-0012

Božić, S., Vujičić, M. D., Kennell, J., Besermenji, S., Solarević, M. 2018: Sun, sea and shrines: application of analytic hierarchy process (AHP) to assess the attractiveness of six cultural heritage sites in Phuket: Thailand. Geographica Pannonica 22-4. DOI: https://doi.org/10.5937/22-16983

Brushan, N., Rai, K. 2004: Strategic decision making - applying the analytic hierarchy process. New York. César, P. A. B., Stigliano, B., Raimundo, S., Nucci, J. C. 2007: Ecoturismo - Caminhos do Futuro. São Paulo.

Cheng, E. W. L., Li, H. 2002: Construction partnering process and associated critical success factors: quantitative investigation. Journal of Management in Engineering 18-4. DOI: https://doi.org/10.1061/(asce) 0742-597x(2002)18:4(194)

Cheng, E. W. L., Li, H., Ho, D. C. 2002: Analytic hierarchy process (AHP) a defective tool when used improperly. Measuring Business Excellence 6-4. DOI: https://doi.org/10.1108/13683040210451697

Ćirić, J. 2006: Gradište - hronika sela. Niš.

Coyne, I. T. 1997: Sampling in qualitative research. Purposeful and theoretical sampling; merging or clear boundaries? Journal of Advanced Nursing 26-3. DOI: https://doi.org/10.1046/j.1365-2648.1997.t01-25-00999.x

Creswell, J. W. 2007: Qualitative inquiry and research design. Choosing among five approaches. Thousand Oaks.

Cvetković, N. J., Dimitrijević, V. M. 2014: Cave bears (Carnivora, Ursidae) from the Middle and Late Pleistocene of Serbia: a revision. Quaternary International 339-340. DOI: https://doi.org/10.1016/j.quaint.2013.10.045

Ham, S. H. 1992: Environmental interpretation - A practical guide for people with big ideas and small budgets. Orlando.

Harker, P. T., Vargas, L. G. 1987: The theory of ratio scale estimation: Saaty's analytic hierarchy process. Management Science 33-11. DOI: https://doi.org/10.1287/mnsc.33.11.1383

Henriques, M. H., dos Reis, R. P., Brilha, J., Mota, T. 2011: Geoconservation as an emerging geoscience. Geoheritage 3. DOI: https://doi.org/10.1007/s12371-011-0039-8

Hose, T. A. 1995: Selling the story of Britain's stone. Environmental Interpretation 10-2.

Hose, T. A. 1997: Geotourism - selling the Earth to Europe. Engineering Geology and the Environment. Rotterdam.

Hose, T. A. 2000: European geotourism - geological interpretation and geoconservation promotion for tourists. Geological Heritage: Its Conservation and Management. Madrid.

Hose, T. A. 2011: The English origins of geotourism (as a vehicle for geoconservation) and their relevance to current studies. Acta geographica Slovenica 51-2. DOI: https://doi.org/10.3986/AGS51302

Hose, T. A. 2016: Three centuries (1670-1970) of appreciating physical landscapes. Appreciating Physical Landscapes: Three Hundred Years of Geotourism. London. DOI: https://doi.org/10.1144/SP417.15

Hose, T. A., Marković, S. B., Komac, B., Zorn, M. 2011: Geotourism - a short introduction. Acta geographica Slovenica. 51-2. DOI: https://doi.org/10.3986/AGS51301

Hsu, T. K., Tsai, Y. F., Wu, H. H. 2009: The preference analysis for tourist choice of destination: a case study of Taiwan. Tourism Management 30-2. DOI: https://doi.org/10.1016/j.tourman.2008.07.011

Jandrić, Z., Srđević, B. 2000: Analitički hijerarhijski proces kao podrška donošenju odluka u vodoprovredi. Vodoprivreda 32.

Jovanović, Dj. 1891: Sićevačka klisura, pećine, dupke i potkapine. Beograd.

Komac, B., Zorn, M. and Erhartič, B. 2011: Loss of natural heritage from the geomorphological perspective - do geomorphic processes shape or destroy the natural heritage? Acta geographica Slovenica 51-2, DOI: https://doi.org/10.3986/AGS51306

Kostić, M. 1954: Fizičko-geografske i privredno-geografske odlike sliva Jelašničke reke. Zbornik radova Geografskog zavoda Prorodno-matematičkog fakulteta Univerziteta u Beogradu 1.

Kostić, M., Martinović, Ž. 1967: Ostrovičke terme - prilog proučavanju termalnih izvora Srbije. Zbornik radova Geografskog instituta Jovan Cvijić, 21.

Krumin, S. 2006: Sićevski kolopleti. Niš.

Lam, K., Zhao, X. 1998: An application of quality function deployment to improve the quality of teaching. International Journal of Quality and Reliability Management 15-4. DOI: https://doi.org/10.1108/ 02656719810196351 
Đorđije Vasiljević, Milica Began, Miroslav Vujičić, Thomas Hose, Uglješa Stankov, Does geosite interpretation lead to ...

Larwood, J. 2016: Geoconservation: an introduction to European principles and practices. Geoheritage and Geotourism. A European Perspective. Woodbridge.

Making tourism more sustainable: a guide for policy-makers. UNEP and UNWTO. Madrid, Paris, 2005.

Mastrini, V., Bonomi, S., Hulubei, D., Mihnevici, L., Toporascu, L., Sa, F., Mor, A., Phanor, D., Antonopoulos, P., Kotsoni, A., Archimandritis, G. Debonis, E. 2018: Study on ecotourism development. Brussels. Internet: https://epale.ec.europa.eu/sites/default/files/study-on-ecotourism_final-pub.pdf (13. 12. 2020).

Mitić, D. 2006: Srednje Ponišavlje: osnove strategije zaštite prirodnih i stvorenih vrednosti. Niš.

Moreira, J. C. 2012: Interpretative panels about the geological heritage - a case study at the Iguassu Falls National Park (Brazil). Geoheritage 4. DOI: https://doi.org/10.1007/s12371-012-0053-5

Murta, S. M., Albano, C. 2005: Interpretar o Patrimônio: um exercício do olhar. Belo Horizonte.

National Geographic Srbija 2016: Sićevo, srpska Kapadokija. Internet: https://www.nationalgeographic.rs/vesti/ 9277-sicevo-srpska-kapadokija.html?p=2 (06. 12. 2016).

Nunes, M. L. 1991: Interpretação da natureza. Paper para o Mestrado em Engenharia Florestal. Universidade Federal do Paraná, Curitiba.

Petrović, M. D., Vasiljević, Dj. A., Vujičić, M. D., Hose, T. A., Marković, S. B., Lukić, T. 2013: Global geopark and candidate - Comparative analysis of Papuk Mountain Geopark (Croatia) and Fruska Gora Mountain (Serbia) by using GAM model. Carpathian Journal of Earth and Environmental Sciences 8-1.

Pierssene, A. 1999: Explaining our world: an approach to the art of environmental interpretation. London.

Roksandić, M., Mihailović, D., Mercier, N., Dimitrijević, V., Morley, M. W., Rakočević, Z., Mihailović, B., Guibert, P., Babb, J. 2011: A human mandible (BH-1) from the Pleistocene deposits of Mala Balanica cave (Sićevo Gorge, Nis, Serbia). Journal of Human Evolution 61-2. DOI: https://doi.org/10.1016/j.jhevol.2011.03.003

Saaty, T. L. 1980: The Analytic Hierarchy Process. New York.

Scholl, A., Manthey, L., Helm, R., Steiner, M. 2005: Solving multi attribute design problems with analytic hierarchy process and conjoint analysis: an empirical comparison. European Journal of Operational Research 164-3. DOI: https://doi.org/10.1016/j.ejor.2004.01.026

Stankov, U., Vasiljević, Đ., Jovanović, V., Kranjac, M., Vujičić, M. D., Morar, C., Bucur, L. 2019: Shared aerial drone videos-prospects and problems for volunteered geographic information research. Open Geosciences 11-1. DOI: https://doi.org/10.1515/geo-2019-0037

Štrba, L., Baláž, B., Lukáč, M. 2016: Roadside geotourism - An alternative approach to geotourism. e-Review of Tourism Research 13-5,6.

Theodossiou-Drandaki, I, 2000: No conservation without education. Geological Heritage: Its Conservation and Management. Madrid.

Tilden, F. 1977: Interpreting our heritage. Chapel Hill.

Tourism and recreation research unit, 1983: Recreation site survey manual: methods and techniques for conducting visitor surveys. London.

Vasconcelos, J. 2003: Interpretação ambiental. Manual de ecoturismo de base comunitária. Brasília.

Vasiljević, D. A., Marković, S. B., Vujičić, M. D. 2016: Appreciating loess landscapes through history: the basis of modern loess geotourism in the Vojvodina region of North Serbia. Appreciating Physical Landscapes: Three Hundred Years of Geotourism. London. DOI: https://doi.org/10.1144/SP417.5

Vasiljević, Dj. A., Marković, S. B., Hose, T. A., Smalley, I., O’Hara-Dhand, K., Basarin, B., Lukić, T., Vujičić, M. D. 2011: Loess towards (geo)tourism - proposed application on loess in Vojvodina region (north Serbia). Acta geographica Slovenica. 51-3. DOI: https://doi.org/10.3986/AGS51305

Višnić, T., Spasojević, B., Vujičić, M. 2016: The potential for geotourism development on the Srem Loess Plateau based on a preliminary geosite assessment model (GAM). Geoheritage 8. DOI: https://doi.org/10.1007/ s12371-015-0149-9

Vujičić, M. D, Stamenković, I., Stankov, U., Kovačić, S., Vasiljević Đ. A, Popov Locke, J. 2020: What will prevail within city break travel, motivation or demotivation? Case study of Novi Sad, Vojvodina, Serbia. Geographica Pannonica 24-1. DOI: https://doi.org/10.5937/gp24-22613

Vujičić, M. D, Vasiljević D. A., Hose T. A., Tasić N., Morar, C., Đurić, A., Marković S. B. 2018: A multicriteria decision analysis with special reference to loess and archaeological sites in Serbia. Open Geoscience 10-1. DOI: https://doi.org/10.1515/geo-2018-0026

Vujičić, M. D., Vasiljević, Dj. A., Marković, S. B., Hose, T. A., Lukić, T., Hadžić, O., Janićević, S. 2011: Preliminary geosite assessment model (GAM) and its application on Fruška Gora mountain, potential geotourism destination of Serbia. Acta geographica Slovenica 51-2. DOI: https://doi.org/10.3986/AGS51303 
Werner, J. P. 1996: La interpretación: un método dinámico para promover el uso social del patrimonio cultural y natural. Difusión del patrimonio histórico 19-9.

Wong, J. K. W., Li, H. 2008: Application of the analytic hierarchy process (AHP) in multi-criteria analysis of the selection of intelligent building systems. Building and Environment 43-1. DOI: https://doi.org/ 10.1016/j.buildenv.2006.11.019

Xu, K., Neto de Carvalho, C., Li, Z., Cui, Z., Yu, G. 2015: Tianzhushan global geopark: new ideas for interpreting geoheritage. European Geoparks Conference 2015. Rokua. 